\title{
Zaczyny cementowe jako ciecze reoniestabilne
}

Proces cementowania kolumn rur okładzinowych w głębokich otworach wiertniczych wymaga, aby zaczyny cementowe były przetłaczalne w dłuższym okresie czasu, a zatem celowym jest wykonywanie badań właściwości reologicznych w funkcji czasu, jaki upływa od sporządzenia zaczynu do górnej granicy jego przetłaczalności. Dzięki badaniom stwierdzono, że zaczyny te mogą wykazywać zjawisko tiksotropii. Polega ono na tym, że na skutek niszczenia wewnętrznej struktury zaczynu (forma żelu) następuje izotermiczne zmniejszenie się tarcia wewnętrznego z upływem czasu ścinania (rozpad ziaren cementu), jak również dający się zmierzyć w czasie powolny powrót do pierwotnej konsystencji w czasie spoczynku. Zmiana lepkości pozornej układu tiksotropowego w funkcji czasu powoduje powstanie pętli histerezy naprężeń przy określaniu krzywej płynięcia, tj. wyznaczeniu naprężeń ścinających przy wzrastających i malejących szybkościach ścinania. Z kolei wielkość pętli histerezy naprężeń określa wielkość tiksotropii układu. Pętla histerezy może mieć różny kształt, w zależności od warunków przebiegu badań laboratoryjnych. Zmiana szybkości ścinania oraz krzywe (pętle) przecinające się przy pośrednich szybkościach ścinania mogą utrudniać interpretację tiksotropii, ponieważ w takich przypadkach powierzchnia pola pętli nie jest równoznaczna $\mathrm{z}$ wielkością tiksotropii. W artykule przedstawiono wyniki badań laboratoryjnych określających wpływ funkcji czasu na zmiany właściwości reologicznych świeżych zaczynów cementowych sporządzanych na osnowie cementu wiertniczego marki Dyckerhoff (API Class G HSR - Black Label, produkt importowany z Niemiec). W przeprowadzanych badaniach zmiennymi były: współczynnik wodno-cementowy, czas pomiaru (liczony od zarobienia zaczynu). Współczynniki wodno-cementowe dla badanych zaczynów cementowych były zmienne i wynosily odpowiednio: 0,45; 0,55 i 0,65.

Słowa kluczowe: cement wiertniczy klasy G, reologia, modele reologiczne, zaczyny cementowe, tiksotropia, pętla histerezy, wytrzymałość strukturalna.

\section{Cement slurries as rheological unstable liquids}

The process of cementing casing columns in deep boreholes requires that the cement slurries were pumped over a longer period of time, so by all means it is advisable to perform studies of rheological properties as a function of time that elapses from the preparation to the upper limit of the possibility of its circulation. Studies show that the slurries may exhibit the phenomenon of thixotropy. This phenomenon consists in the fact, that due to the destruction of the internal structure of the slurry (gel form), followed by the isothermal reduction of internal friction with the passage of coagulation time (decay of particles of cement), as well as a measurable during the time slow return to its original consistency at rest. Changing the apparent viscosity of the thixotropic system in a function of time creates a strain hysteresis loop when determining the flow curve, i.e. designation stress at increasing and decreasing coagulation rates. The size of strain hysteresis loop determines the size of the system thixotropy. The hysteresis loop can have different shapes depending on the course of laboratory tests. Changing the coagulation rate and the curves (loops) intersecting at intermediate coagulation rates may hinder interpretation of thixotropy, because in such cases the surface of the loop field is not equivalent to the size of thixotropy. The article presents results of laboratory tests defining the influence of the function of time on changes in the rheological properties of fresh cement slurries prepared on the base of the drill Class G cement, grade HSR (cement imported from Germany). In the study performed the variables were: the ratio of w/c, the measurement time(counted from mixing the slurry). Water-cement ratios for the tested cement slurries were variable and amounted to $0.45 ; 0.55$ and 0.65 .

Key words: class G cement drilling, rheology, rheological models, cement slurries, thixotropy, hysteresis loop, structural strength. 


\section{Wstęp}

Właściwości reologiczne zaczynów uszczelniających są bardzo istotne zarówno podczas projektowania, jak i realizacji prac związanych z uszczelnianiem i wzmacnianiem ośrodka gruntowego i masywu skalnego metodami geoinżynieryjnymi wykorzystującymi technikę iniekcji otworowej $[1,2,9]$.

Znajomość przebiegu podstawowych reakcji chemicznych oraz zjawisk fizycznych, jakie zachodzą w zaczynie cementowym podczas procesów hydratacji i hydrolizy, jest jednym z najważniejszych warunków optymalnego ich stosowania. Ważną rolę odgrywa duże zróżnicowanie pod względem zarówno składników zaczynu, jak i występujących w nim faz (początkowo jest to układ trójfazowy, lecz w miarę postępu procesu hydratacji następuje jego zmiana w układ wielofazowy). Dodatkowym czynnikiem warunkującym tempo zmian właściwości reologicznych zaczynów cementowych w funkcji czasu jest zmienny zakres jego prędkości przepływu w trakcie realizacji poszczególnych etapów cementowania kolumn rur okładzinowych - zatłaczania zaczynu do otworu i wytłaczania go do przestrzeni pierścieniowej $[3,5,10]$.

Wszystkie te czynniki traktowane są jako zmienne technologiczne i wpływają bezpośrednio na właściwości reologiczne zaczynów cementowych. Reologiczne własności zaczynu są wypadkową interakcji między tymi zmiennymi oraz zależą od odpowiedniego uformowania się jego struktur - dostosowania ich do wymagań. Przedmiotem badań reologicznych jest właśnie zapewnienie efektywnego przebiegu procesów tworzenia zaczynu poprzez zagwarantowanie optymalnego współdziałania wszystkich wyżej wymienionych czynników.

Zmieniające się wraz z upływem czasu właściwości reologiczne mogą w konsekwencji wpływać na konsystencję oraz wzrost wytrzymałości w czasie (wiązanie i twardnienie). Wszystkie te parametry mają swoje odpowiedniki w charakterystyce reologicznej zaczynu, która z kolei jest określona składem fazowym klinkieru oraz typem cementu, a więc głównie rodzajem i ilością domieszek i dodatków (hydraulicznych lub pucolanowych) $[5,8,12]$.

W związku z powyższym zaczyny cementowe mogą charakteryzować się różnymi właściwościami reologicznymi. Krzywe płynięcia mogą być odwracalne lub wykazywać histerezę. Spowodowane to może być między innymi tym, że przy krótkich czasach pomiaru dominujące jest niszczenie struktury zaczynu, natomiast przy dłuższych czasach - jej odbudowa. A zatem w świeżych zaczynach cementowych występuje nakładanie się procesów niszczenia struktury pod wpływem ścinania w lepkościomierzu i jej odbudowy przez produkty hydratacji ziaren cementu.

Pomimo wielu badań laboratoryjnych oraz doświadczeń realizowanych w różnych jednostkach naukowo-badawczych na przestrzeni ostatnich 20 lat $[4,6,7,11,14]$, do chwili obecnej nie została w pełni dokonana kompleksowa ocena zaczynów cementowych pod kątem ich usystematyzowania w aspekcie reologicznym. Wynika to między innymi z faktu, że reologia zaczynów uszczelniających jest bardzo skomplikowana i zależy od wielu czynników natury fizykochemicznej $[2,3,5,8,13]$.

\section{Wpływ czasu cementowania kolumn rur okładzinowych na właściwości reologiczne zaczynów cementowych}

Wieloletnie badania laboratoryjne prowadzone w Katedrze Wiertnictwa i Geoinżynierii na Wydziale Wiertnictwa, Nafty i Gazu AGH odnośnie właściwości reologicznych zaczynów cementowych wykazują, że zaczyny te w pierwszym okresie po sporządzeniu w $90 \%$ pod względem reologicznym opisywane są modelem Herschel-Bulkleya $[2,12,13]$.

W związku z tym, że proces uszczelniania ośrodka gruntowego i masywu skalnego wymaga stosowania zaczynu o odpowiednich parametrach reologicznych, celowym jest wykonywanie badań reologicznych w funkcji czasu, począwszy od momentu sporządzenia do górnej granicy jego przetłaczalności. Badania reologiczne dowodzą, że zaczyny te mogą wykazywać zjawisko tiksotropii. Polega ono na tym, że na skutek niszczenia wewnętrznej struktury zaczynu (forma żelu) następuje izotermiczne zmniejszenie się tarcia wewnętrznego $\mathrm{z}$ upływem czasu ścinania (rozpad ziaren cementu), jak również dający się zmierzyć w czasie powolny powrót do pierwotnej konsystencji w czasie spoczynku [3].

Zmiana lepkości pozornej układu tiksotropowego w funkcji czasu powoduje powstanie pętli histerezy naprężeń przy określaniu krzywej płynięcia, tj. wyznaczeniu naprężeń przy wzrastających i malejących szybkościach ścinania. Z kolei wielkość pętli histerezy naprężeń określa wielkość tiksotropii układu.

Pętla histerezy może mieć różny kształt, w zależności od warunków przebiegu badań laboratoryjnych (szybkości ścinania, czasu pomiarów, długości mieszania itp.). Zmiana szybkości ścinania oraz krzywe (pętle) przecinające się przy pośrednich szybkościach ścinania mogą utrudniać interpretację tiksotropii, ponieważ $\mathrm{w}$ takich przypadkach powierzchnia pola pętli nie jest równoznaczna $\mathrm{z}$ wielkością tiksotropii. Należy również wziąć pod uwagę to, że naprężenia ścinające w cieczach tiksotropowych zależą od [3]: 
- naprężeń stycznych,

- czasu ścinania,

- historii ścinania.

Przy analizowaniu układów tiksotropowych istotne jest ustalenie rodzaju ścinania oraz wyeliminowanie wpływu historii ścinania np. przez intensywne mieszanie.

Jeszcze do niedawna w przemyśle wiertniczym nie zajmowano się kwestią komplementarnej charakterystyki tiksotropii zaczynów cementowych [14]. Wysoka wartość naprężeń ścinających na początku standardowych testów wymaga zniszczenia struktury zaczynu przed przystąpieniem do określania parametrów reologicznych. Zakłada się, że przy maksymalnych wartościach naprężeń ścinających 60 sekund to czas wystarczający dla osiągnięcia równowagi w strukturze badanego zaczynu. Podobny efekt można osiągnąć, obniżając prędkość mieszania zaczynu i mieszając go przez okres 20 sekund przed każdorazowym odczytem z pomiaru. Okres ten może być jednak zbyt długi lub zbyt krótki, w zależności od tego, czy struktura zaczynu była uprzednio zniszczona, czy też nienaruszona. W ten sposób aktualna procedura nie jest praktycznie adaptowana do badania tiksotropowych cementów, jak również nie nadaje się do ustalenia, czy dany zaczyn lub płyn wykazuje tiksotropowe właściwości, czy też nie.

Wówczas analizy histerezy naprężeń mogłyby dać przynajmniej ogólną ocenę tiksotropowego charakteru danego zaczynu.

Tymczasem termin ,tiksotropia”, używany powszechnie w przemyśle naftowym, jest popularnie związany ze zdolnością danego płynu do budowania struktury po pewnym czasie postoju. Struktura taka najczęściej określona jest wartością wytrzymałości strukturalnej, co z kolei oznacza użycie minimum naprężeń ścinających wymaganych do uzyskania przepływu danego płynu. Niestety wyniki otrzymane z wykorzystaniem procedur badawczych związanych z płuczkami wiertniczymi budzą wątpliwości z dwóch względów $[3,5,8]$ :

- zachowanie się zaczynów cementowych przy niskich wartościach naprężeń ścinających jest często zdefiniowane przez zjawisko poślizgu na ściance. Jest to bardziej istotne w przypadku systemów tiksotropowych, gdzie zjawisko poślizgu uwydatnia się w jeszcze większym stopniu;

- wyniki pomiarów otrzymane w trakcie badań zmieniaja się w zależności od stosowanych wiskozymetrów oraz warunków pomiarowych.

\section{Metodyka badań laboratoryjnych}

Badania laboratoryjne parametrów reologicznych zaczynów cementowych przeprowadza się w oparciu o normę PN-EN ISO 10426-2 Przemyst naftowy i gazowniczy. Cementy i materiaty do cementowania otworów. Część 2: Badania cementów wiertniczych, 2006.

Przeprowadzone badania laboratoryjne miały na celu określenie wpływu funkcji czasu na zmiany właściwości reologicznych świeżych zaczynów cementowych sporządzanych na osnowie cementu wiertniczego klasy G. Do przygotowania zaczynów cementowych użyto cementu wiertniczego marki Dyckerhoff (API Class G HSR - Black Label, produkt importowany z Niemiec).

W przeprowadzanych badaniach zmiennymi były:

a) współczynnik wodno-cementowy,

b) czas pomiaru (liczony od zarobienia zaczynu).

Współczynniki wodno-cementowe dla badanych zaczynów uszczelniających były zmienne i wynosiły odpowiednio: 0,$45 ; 0,55$ i 0,65 . Temperatura wody zarobowej (woda wodociągowa) do sporządzania zaczynu suchego cementu, podobnie jak temperatura mieszalnika oraz mieszadła, miała wartość $23^{\circ} \mathrm{C} \pm 1^{\circ} \mathrm{C}\left(73^{\circ} \mathrm{F} \pm 2^{\circ} \mathrm{F}\right)$.

Badania laboratoryjne związane z określeniem parametrów reologicznych świeżych zaczynów uszczelniających wykonywano za pomocą lepkościomierza obrotowego o współosiowych cylindrach typu Chan-35 API Viscometer - Tulusa, Oklahoma USA EG.G Chandler Engineering, o dwunastu prędkościach obrotowych $(600,300,200,100,60,30$, 20, 10, 6, 3, 2, 1 obr./min, co odpowiada szybkościom ścinania: 1022,$04 ; 511,02 ; 340,7 ; 170,4 ; 102,2 ; 51,1 ; 34,08$; 17,$\left.04 ; 10,22 ; 5,11 ; 3,41 ; 1,70 \mathrm{~s}^{-1}\right)$. Badania parametrów reologicznych świeżych zaczynów cementowych przeprowadzono po ich sporządzeniu oraz po upływie $1 \mathrm{~h}, 2 \mathrm{~h}$ oraz $3 \mathrm{~h}$.

\section{Wyniki badań laboratoryjnych}

Otrzymane wyniki badań laboratoryjnych, których celem było określenie zależności naprężeń stycznych od szybkości ścinania świeżych zaczynów cementowych sporządzonych w oparciu o cement wiertniczy klasy G, zestawiono w tablicach 1, 2 i 3.

Na rysunkach 1-3 przedstawiono zmiany naprężeń ścinających w funkcji szybkości ścinania, w zależności od upływającego czasu od chwili zarobienia zaczynu (wiązania zaczynu). Krzywe histerezy zostały wykreślone na podstawie krzywych płynięcia uzyskanych na podstawie odczytów z lepkościomierza dla rosnącej, a następnie dla malejącej szybkości ścinania. 
Tablica 1. Odczyty z lepkościomierza obrotowego dla współczynnika w/c wynoszącego 0,45, dla czasu pomiaru równego 1, 60, 120, 180 minut od zarobienia zaczynu uszczelniającego

\begin{tabular}{|c|c|c|c|c|}
\hline $\begin{array}{c}\text { Odczyt z wiskozymetru } \\
\text { [obr./min] }\end{array}$ & Świeży & Po $1 \mathrm{~h}$ & Po $2 \mathrm{~h}$ & Po $3 \mathrm{~h}$ \\
\hline 1 & 10 & 10 & 11 & 12 \\
\hline 2 & 12 & 13 & 14 & 14 \\
\hline 3 & 13 & 15 & 17 & 19 \\
\hline 6 & 18 & 21 & 23 & 24 \\
\hline 10 & 24 & 28 & 31 & 33 \\
\hline 20 & 33 & 39 & 43 & 49 \\
\hline 30 & 37 & 46 & 51 & 58 \\
\hline 60 & 47 & 59 & 66 & 72 \\
\hline 100 & 56 & 72 & 80 & 95 \\
\hline 200 & 77 & 101 & 113 & 135 \\
\hline 300 & 96 & 127 & 142 & 162 \\
\hline 600 & 151 & 192 & 222 & 250 \\
\hline
\end{tabular}

Tablica 2. Odczyty z lepkościomierza obrotowego dla współczynnika w/c wynoszącego 0,55, dla czasu pomiaru równego 5, 60, 120, 180 minut od zarobienia zaczynu uszczelniającego

\begin{tabular}{|c|c|c|c|c|}
\hline $\begin{array}{c}\text { Odczyt z wiskozymetru } \\
\text { [obr./min] }\end{array}$ & Świeży & Po $1 \mathrm{~h}$ & Po $2 \mathrm{~h}$ & Po $3 \mathrm{~h}$ \\
\hline 1 & 4 & 6 & 6 & 7 \\
\hline 2 & 6 & 8 & 7 & 8 \\
\hline 3 & 8 & 10 & 9 & 11 \\
\hline 6 & 9 & 11 & 11 & 13 \\
\hline 10 & 10 & 13 & 13 & 16 \\
\hline 20 & 12 & 14 & 15 & 18 \\
\hline 30 & 13 & 16 & 17 & 20 \\
\hline 60 & 16 & 19 & 22 & 25 \\
\hline 100 & 22 & 24 & 26 & 32 \\
\hline 200 & 35 & 38 & 40 & 43 \\
\hline 300 & 45 & 50 & 55 & 60 \\
\hline 600 & 70 & 72 & 82 & 90 \\
\hline
\end{tabular}

Tablica 3. Odczyty z lepkościomierza obrotowego dla współczynnika w/c wynoszącego 0,65, dla czasu pomiaru równego 1, 60, 120, 180 minut od zarobienia zaczynu uszczelniającego

\begin{tabular}{|c|c|c|c|c|}
\hline $\begin{array}{c}\text { Odczyt z wiskozymetru } \\
\text { [obr./min] }\end{array}$ & Świeży & Po $1 \mathrm{~h}$ & Po $2 \mathrm{~h}$ & Po $3 \mathrm{~h}$ \\
\hline 1 & 4 & 5 & 6 & 7 \\
\hline 2 & 6 & 6 & 7 & 8 \\
\hline 3 & 7 & 7 & 7 & 8 \\
\hline 6 & 8 & 8 & 8 & 8 \\
\hline 10 & 9 & 9 & 9 & 9 \\
\hline 20 & 10 & 11 & 11 & 11 \\
\hline 30 & 11 & 12 & 13 & 14 \\
\hline 60 & 14 & 15 & 17 & 19 \\
\hline 100 & 17 & 20 & 22 & 25 \\
\hline 200 & 23 & 25 & 28 & 31 \\
\hline 300 & 27 & 31 & 34 & 37 \\
\hline 600 & 40 & 46 & 49 & 53 \\
\hline
\end{tabular}




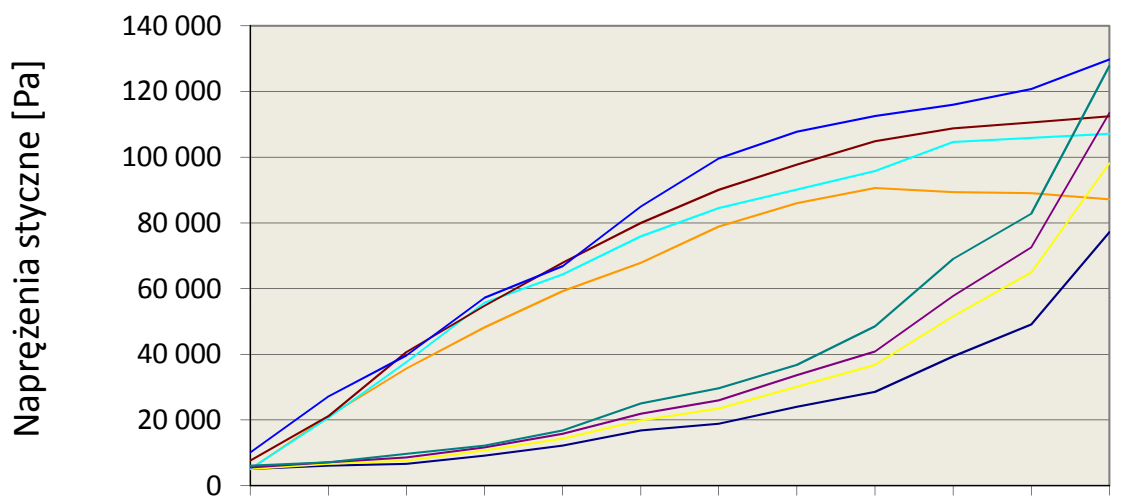

_-wartości rosnące po $5 \mathrm{~min}$

- wartości malejące po $5 \mathrm{~min}$

wartości rosnące po $1 \mathrm{~h}$

wartości malejące po $1 \mathrm{~h}$

— wartości rosnące po $2 \mathrm{~h}$

— wartości malejące po $2 \mathrm{~h}$

— wartości rosnące po $3 \mathrm{~h}$

— wartości malejące po $3 \mathrm{~h}$

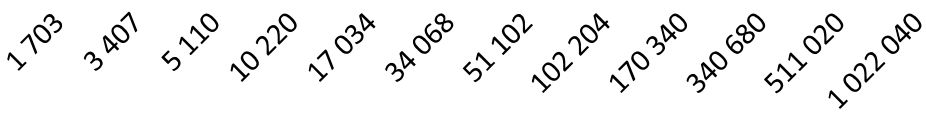

Szybkość ścinania [1/s]

Rys. 1. Zależność naprężeń stycznych od szybkości ścinania w funkcji czasu dla próbki o w/c $=0,45$

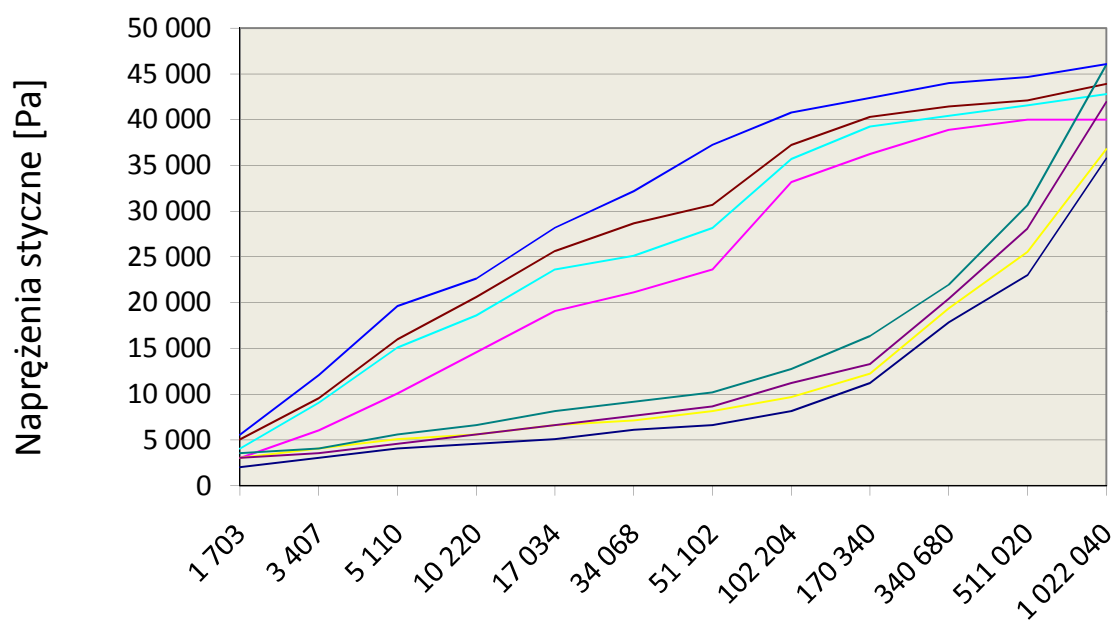

— wartości rosnące po $5 \mathrm{~min}$

— wartości malejące po $5 \mathrm{~min}$

wartości rosnące po $1 \mathrm{~h}$

wartości malejące po $1 \mathrm{~h}$

— wartości rosnące po $2 \mathrm{~h}$

— wartości malejące po $2 \mathrm{~h}$

— wartości rosnące po $3 \mathrm{~h}$

— wartości malejące po $3 \mathrm{~h}$

\section{Szybkość ścinania [1/s]}

Rys. 2. Zależność naprężeń stycznych od szybkości ścinania $\mathrm{w}$ funkcji czasu dla próbki o w/c $=0,55$
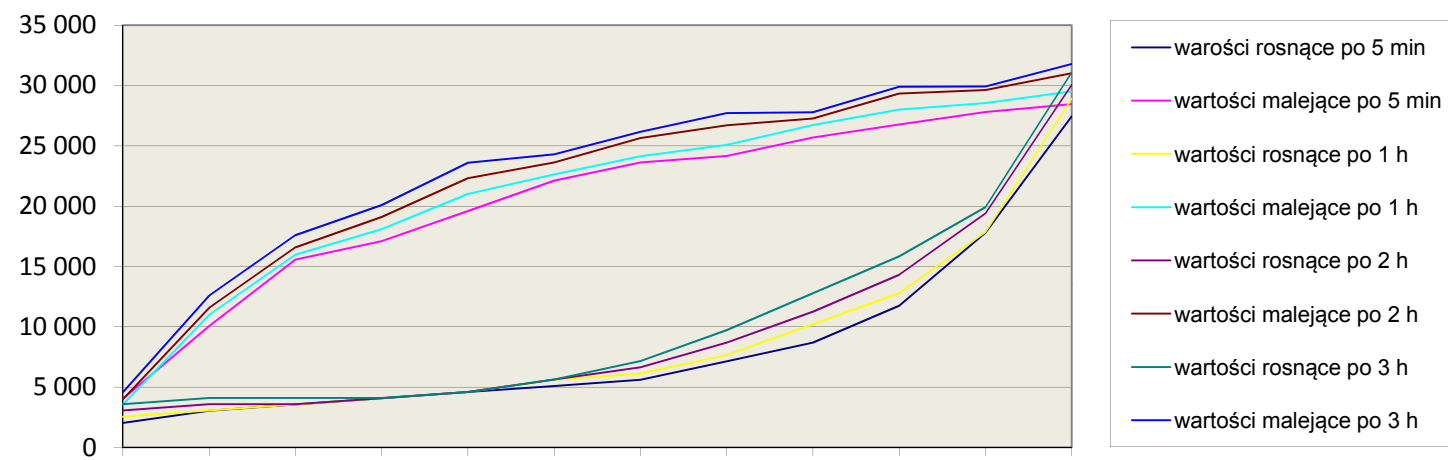

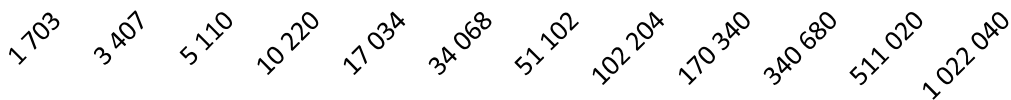

Szybkość ścinania [1/s]

Rys. 3. Zależność naprężeń stycznych od szybkości ścinania w funkcji czasu dla próbki o w/c $=0,65$ 


\section{Omówienie wyników badań laboratoryjnych}

Zjawisko histerezy uwidacznia się na reogramie wtedy, gdy przebieg krzywej płynięcia przy wzrastającej szybkości ścinania nie pokrywa się z jej przebiegiem przy malejącej szybkości ścinania w tym samym jej zakresie. W typowych pomiarach reologicznych naprężenie ścinania lub szybkość ścinania zmienia się od wartości minimalnej do maksymalnej i wraca z powrotem do minimalnej wartości, tworząc pętlę histerezy. Zawiesina wykazuje wtedy przepływ tiksotropowy lub reopeksyjny, tj. uzależniony od czasu ścinania, w którym pojawiają się warunki różnego rozpraszania energii. Jeśli dolna krzywa płynięcia występuje przy malejącej szybkości ścinania, wówczas tworzy się pętla tiksotropowa, a jej powierzchnia może być miarą tiksotropii. W przypadku, gdy dolna krzywa płynięcia pojawia się przy wzrastającej szybkości ścinania, pętla jest miarą antytiksotropii. W przypadku zawiesin ceramicznych pętla reopeksji praktycznie nie występuje [3].

Na podstawie analizy wyników uzyskanych z badań laboratoryjnych można stwierdzić, że badane zaczyny odznaczają się własnościami antytiksotropowymi - konsystencja zaczynu jest zmienna w czasie. Wraz z upływem czasu ścinania następuje niszczenie wewnętrznej struktury, a po pozostawieniu zaczynu w bezruchu struktura ta ulega odbudowie.
Przy danym współczynniku wodno-cementowym siła spójności oraz odporność na siły ścinające są tym wyższe, im większa jest powierzchnia właściwa cementu. W związku z tym zaczyny uszczelniające mogą charakteryzować się różnymi właściwościami reologicznymi. Krzywe płynięcia mogą być odwracalne lub wykazywać histerezę. Spowodowane to może być między innymi tym, że przy krótkich czasach pomiaru dominujące jest niszczenie struktury zaczynu, natomiast przy dłuższych czasach przeważa jej odbudowa. Zatem w świeżych zaczynach cementowych występuje nakładanie się procesów niszczenia struktury pod wpływem ścinania w lepkościomierzu i jej odbudowy przez produkty hydratacji ziaren cementu.

Sytuację tę wyraźnie obrazują wykreślone pętle histerezy (rysunki 1-3). Na wykresach tych widać, że wraz z biegiem czasu, jaki upływa od zarobienia zaczynu, wartości te rosną, skutkiem czego pętle histerezy znajdują się coraz wyżej.

Równocześnie dla każdego z przebadanych zaczynów parametry te rosną wraz z upływem czasu, chociaż tempo przyrostu dla poszczególnych próbek jest różne (zmniejsza się wraz ze wzrostem w/c).

Budowa struktury wewnętrznej badanych zaczynów cementowych zachodzi szybciej niż jej niszczenie - zatem wykazują one tiksotropię ujemną.

Prosimy cytować jako: Nafta-Gaz 2015, nr 10, s. 747-753

Artykuł nadesłano do Redakcji 24.03.2015 r. Zatwierdzono do druku 22.04.2015 r.

Praca została wykonana w ramach badań statutowych realizowanych w Katedrze Wiertnictwa i Geoinżynierii na Wydziale Wiertnictwa, Nafty i Gazu AGH (nr 11.11.190.555, zad. 2).

\section{Literatura}

[1] Bujok P., Porzer M., Labus K., Klempa M., Pavlus J.: Experimental modeling of abandoned shallow oil wells convergence. Engineering Geology 2013, 157, pp. 1-7. DOI: 10.1016/j. enggeo.2013.02.004.

[2] Gonet A., Stryczek S.: Reologia wybranych zaczynow uszczelniajacych wykonanych z cementow Gorazdze Cement S.A. Sympozjum Naukowo-Techniczne „Cementy w budownictwie, robotach wiertniczych i inżynieryjnych oraz hydrotechnice", Piła 2001

[3] Izak P.: Reologia zawiesin ceramicznych. Wydawnictwo AGH, Kraków 2012.

[4] Jasiczak J., Mikolajczak P.: Technologia betonu modyfikowanego domieszkami i dodatkami. Wydawnictwo Politechniki Poznańskiej, Poznań 1997

[5] Kurdowski W.: Chemia cementu. PWN, Warszawa 1991.

[6] Mierzwa J.: Wlasciwosci reologiczne zaczynow cementowych stosowanych $w$ wybranych procesach technologicznych budownictwa. Monografia Politechniki Krakowskiej im. Tadeusza Kościuszki, Kraków 1988.

[7] Nelson E. B.: Cementowanie otworow wiertniczych. Schlumberger Educational Service, Houston, Texas, USA, 1990.
[8] Piklowska A.: Okreslenie zmian wlasciwosci reologicznych zaczynow cementowych $w$ funkcji czasu wiazania. WWNiG AGH (praca niepublikowana), Kraków 2013.

[9] Pinka J., Wittenberger G., Engel.: Dobyvanie lozisk vrtmi. AMS F BERG, TU v Kosiciach, Kosice 2006, 227 s.

[10] Sliwa T.: Badania podziemnego magazynowania ciepla za pomoca kolektorow slonecznych $i$ wymiennikow otworowych. Wydawnictwa AGH, Kraków 2012, s. 265-273.

[11] Szaj P.: Wplyw wybranych dodatkow mineralnych na wlasciwosci reologiczne zaczynow cementowych. Prace Naukowe Instytutu Górnictwa Politechniki Wrocławskiej. Studia i Materiały 2012, vol. 135, nr 41, s. 285-294.

[12] Wisniowski R., Skrzypaszek K.: Analiza modeli reologicznych stosowanych w technologiach inzynierskich. Wydawnictwo AGH „Wiertnictwo, Nafta, Gaz”, Kraków 2006, tom 23, zeszyt 1, s. 523-532.

[13] Wisniowski R., Stryczek S., Skrzypaszek K.: Kierunki rozwoju badan nad reologia plynow wiertniczych. Wydawnictwo AGH „Wiertnictwo, Nafta, Gaz”, Kraków 2007, tom 24, zeszyt 1, s. 595-607. 


\section{Akty prawne i normatywne}

[14] Norma PN-EN ISO 10426-2 Przemyst naftowy i gazowniczy. Cementy i materialy do cementowania otworów wiertniczych. Część 2: Badania cementów wiertniczych, 2006.

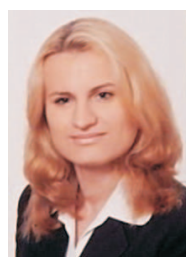

Mgr inż. Anna PIKŁOWSKA

Doktorant w Katedrze Wiertnictwa i Geoinżynierii

Akademia Górniczo-Hutnicza im. St. Staszica

Wydział Wiertnictwa, Nafty i Gazu

al. Mickiewicza 30

30-059 Kraków

E-mail:apiklow@agh.edu.pl

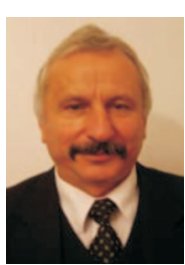

Prof. dr hab. inż. Andrzej GONET

Profesor zwyczajny

Dziekan Wydziału Wiertnictwa, Nafty i Gazu

Akademia Górniczo-Hutnicza im. St. Staszica

al. Mickiewicza 30

30-059 Kraków

E-mail: gonet@agh.edu.pl

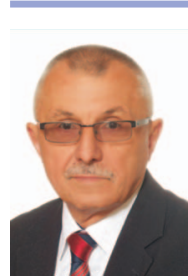

Prof. dr hab. inż. Stanisław STRYCZEK

Profesor zwyczajny

Akademia Górniczo-Hutnicza im. St. Staszica

Wydział Wiertnictwa, Nafty i Gazu

al. Mickiewicza 30

30-059 Kraków

E-mail:stryczek@agh.edu.pl

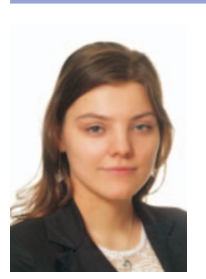

Mgr inż. Małgorzata FORMELA

Doktorant w Katedrze Wiertnictwa i Geoinżynierii

Akademia Górniczo-Hutnicza im. St. Staszica

Wydział Wiertnictwa, Nafty i Gazu

al. Mickiewicza 30

30-059 Kraków

E-mail:mformela@agh.edu.pl

\section{OFERTA}

\section{ZAKŁAD PODZIEMNEGO MAGAZYNOWANIA GAZU}

Zakres działania:

- analiza struktur geologicznych złóż gazu ziemnego, ropy naftowej oraz obiektów zawodnionych, pod kątem możliwości ich przekształcenia w PMG;

- $\quad$ szczegółowa analiza warunków geologiczno-złożowych, ocena dotychczasowej eksploatacji złoża, warunków hydrodynamicznych, zdolności wydobywczych odwiertów;

- ocena stanu technicznego istniejącej infrastruktury w aspekcie jej wykorzystania w pracy PMG;

- $\quad$ wykonywanie cyfrowych modeli geologicznych PMG, złóż gazu ziemnego i ropy naftowej;

- $\quad$ wykonanie projektu budowy PMG;

- $\quad$ analiza dotychczasowej pracy istniejących PMG w celu optymalizacji parametrów dalszej eksploatacji magazynów na bazie symulacji komputerowej;

- opracowanie projektów prac geologicznych, dotyczących poszukiwania i rozpoznawania złóż gazu ziemnego i ropy naftowej;

- opracowanie dokumentacji geologicznych złóż ropy naftowej i gazu ziemnego;

- $\quad$ opracowanie programu optymalnej eksploatacji złoża, wydajności poszczególnych odwiertów, tempa sczerpywania itp.

Kierownik: mgr inż. Bogdan Filar

Adres: ul. Armii Krajowej 3, 38-400 Krosno

Telefon: 13 436-89-41 w. 5202

Faks: 13 436-79-71

E-mail: bogdan.filar@inig.pl

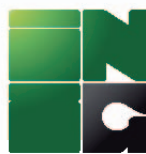

